\title{
Dekonstruksi Peran Pustakawan
}

\author{
Wiji Suwarno \\ Pustakawan IAIN Salatiga
}

\begin{abstract}
The theme of this article is the role of librarians in disruption era. This study uses qualitative research with a phenomenological approach. The informants from this study were librarians from all elements who visited and were met at IAIN Saaltiga. Informant was taken randomly. Data collection is done using interviews and documents. The problem of this research is the strategy to development that threatens to shift the role of librarians. The results of this study are that librarians are required to map their developments, weaknesses, and develop the skills needed according to development. The reliability of the librarian is an advanced point of professionalism which is then oriented to the ability to maintain self quality. Competency is the ability in terms of Listening, Informatin acceptance, Public relations, Social relationships, Time management, Interpersonal, and Communication skills.
\end{abstract}

Kata kunci: soft skill, role of the librarian, and decontruction of the librarian roles

\section{Pendahuluan}

Memperbincangkan mengenai eksistensi pustakawan di era sekarang, mengarahkan satu pemikiran untuk menempatkan posisi pustakawan ini pada posisi yang diperhitungkan dikancah perkembangan ilmu pengetahuan. Betapa tidak, satu mata rantai penting perkembangan itu adalah eksistensi pustakawan. Jika mata rantai putus, maka hakekatnya terputus pula perjalanan ilmu pengetahuan ini. Michael Gorman mendefinisikan pustakawan itu sebagai orang yang sudah dalam level pakar, yang memiliki tugas 
mengembangkan dan mengawal ilmu pengetahuan ${ }^{1}$. Lebih lanjut, Mackellar memandang tugas penting pustakawan pada abad 21 ini diantaranya:

- Selects materials and electronic resources

- Acquires the selected materials and resources

- Organizes and gives access to them

- Preserves and conserves them

- Assists library users

- Instructs library users

- Administers and manages the library, library personnel, services, and programs.

Hanya saja mata masyarakat awam belum banyak yang memandang bahwa satu mata rantai ini penting dan berpengaruh pada perjalanan perkembangan ilmu pengetahuan ini. Maka, upaya mengibarkan eksistensi pustakawan ini perlu diupayakan secara berkelenjutan dengan berbagai kegiatan yang relevan.

Perkembangan teknologi bisa berakibat bergesertnya peran pustakawan. Kekhawatiran ini melihat beberapa tempat kerja seperti gerbang tol yang sudah tidak lagi memerlukan petugas dalam jumlah besar untuk melayani pembayaran tol. Dalam konteks ini, mesin sudah menggantikan persan manusia. Hal yang terpenting adalah bagaimana agar pustakawan tetap eksis di tengah-tengah perkembangan teknologi yang semakin "menjajah" di hampir seluruh aspek kehidupan, tidak terkecuali pada ranah perpustakaan.

Pekerjaan rumah terbesar perpustakaan adalah mempertahankan pustakawan untuk "setia" dengan pekerjaannya diperpustakaan, tanggung jawaba dan berdedikasi. Disksursus ini diarahkan pada eksistensi pustakawan yang "barangkali" hingga sekarang ini masih belum menduduki nilai "baik" di mata masyarakat pada umumnya. Masih perlu perjuaangan lebih ekstra untuk menunjukkan bahwa pustakawan ini mampu sejajar dengan profesi lain. betapa tidak, status pustakawan kini sudah terlanjur masuk pada ranah 2008), 3.

${ }^{1}$ Pamela H. MacKellar, The Accidental Librarian (Medford, N.J: Information Today, Inc, 
professional. Ini artinya ada kualifikasi tertentu bagi seseorang ketika ingin menjadi pustakawan. Ini pula menjadi penanda bahwa pustakawan bukan lagi seperti yang dianggap orang pada masa-masa sebelumnya yang hanya sebagai penjaga buku dan penjaga gunungan kertas di gudang saja.

Ada anggapan bahwa pustakawan sekarang ini memiliki mulitidimensi kehandalan pada wilayah pekerjaan teknis, administrasi dan juga pada pelayanan publik. Kehandalan ini yang kemudian menjadi titik keprofesian seorang pustakawan.

\section{Metode}

Penelitian ini menggunakan jenis penelitian kualitatif dengan pendekatan fenomenologi. Adapun pengumpulan data dengan menggunakan model wawancara dan dokumentasi. Sementara itu penentuan informan menggunakan random sampling dengan mengambil pustakawan yang berkunjung ke Perpustakaan IAIN Salatiga. Interview dilakukan secara random baik pustakawan maupun waktu.

\section{Hasil dan pembahawan}

Pustakawan bekerja selayaknya pada perusahaan besar yang mensyaratkan kesiapan kerja individu dengan berbagai pengalamannya. Tidak cukup sampai disitu, pustakawan era sekarang perlu reorientasi kerja agar produktifitasnya menjadi lebih nampak, tidak sekedar namanya saja sebagai pustakawan. Keterampilan seseorang sesungguhnya dimulai dari keterampilan yang muncul dari dalam diri, maka itu beberapa peneliti mengatakan bahwa keterampilan dalam ini lebih dominant dalam menentukan keberhasilan seseorang ${ }^{2}$. Untuk itu melalui naskah ini, saya mengistilahkan bahwa pustakawan dituntut memiliki kompetensi dalam hal mendengarkan, keterampilan hubungan masyarakat, keterampilan literasi informasi, keterampilan menerima informasi, menggunakan waktu dengan baik, hubungan interpersonal, dan kemampuan berkomunisi yang baik. yang

${ }^{2}$ Marcel M. Robles, "Executive Perceptions of the Top 10 Soft Skills Needed in Today's Workplace," Business Communication Quarterly 75, no. 4 (2012): 458. 
kesemuanya itu tergolong pada jajaran soft skill.

\section{Kemampuan mendengarkan.}

Profesi pustakawan menghendaki individu yang menasbihkan diri sebagai pustakawan harus memiliki kemampuan mendengarkan dengan pengertian sanggup menghargai pendapat orang, mendengarkan ide-ide orang lain, mengindahkan kritik dan saran, mensikapi setiap perbedaan pendapat dengan baik. Hal ini terkait dengan interaksinya dengan pemustaka, antar sesama pustakawan, dengan organisai maupun dengan masyarakat di luar perpustakaan tempatnya pustakawan bekerja. Aspek ini berlaku tanpa kecuali, baik bagi staf maupun pimpinan sekalipun.

Bagi pimpinan, umumnya karena memiliki kekuasaan, biasanya berupaya dengan sekuat tenaga untuk mewujudkan ide yang dimilikinya. Dan secara umum pula, biasanya ada kendala saat seseorang melihat kekuarangan ide atau gagasannya sendiri. Untuk itu ada baiknya mencoba mendiskusikan ide kita itu dengan rekan sekerja, Bahkan jika kebetulan individu itu berposisi sebagai atasan tidak ada salahnya jika berusaha untuk mendiskusikannya dengan bawahan atau stafnya. Dengan cara ini kita sendiri bisa menilai ide kita ini secara netral dan objektif, dan terbuka peluang untuk menyempurnakannya.

Manfaat mendengarkan lawan bicara dalam proses komunikasi diantaranya:

a. Orang lain akan merasa diperhatikan

b. Mendorong orang lain untuk berbicara tentang ide/ gagasannya

c. Membangun hubungan baik

d. Mendengarkan dapat memberi kelegaan bagi si pembicara saat menghadapi masalah. ${ }^{3}$

Meski dalam pergaulan seringkali terjadi kegiatan berdiskusi, ada yang berbicara dan ada yang mendengarkan. Tetapi disini dalam konteks akademis, sesungguhnya mendengarkan ini bertujuan untuk memahmi

\footnotetext{
${ }^{3}$ Teguh Sutatno, Soft Skill Sukses Di Dunia Kerja (Yogyakarta: Buku Pintar, 2012), 115.
} 
dan memperoleh informasi. Lalu kemudian setelah informasi diperoleh, mendengarkan bisa menjadi pintu menganalisa ketepatan informasi yang diterima.

\section{Kemempuan penerimaan informasi}

Information acception skill ini merupakan kemampuan yang dimiliki seseorang tentang reaksi cepat tanggap terhadap informasi yang berkembang. Pustakawan sebagai pelaku informasi, baik kiranya jika memiliki kemampuan ini, yakni menangkap informasi penting, dan kebutuhan informasi pemustakanya. Keterampilan ini seolah individu sebagai filter dari berkeliarannya informasi, maka itu sistem pengolahannya akan melewati jenis pengolahan perseptual, pengolahan intelektual (kognitif), dan pengendalian motorik, yang semuanya berinteraksi dengan memori manusia. Kemampuan tanggap informasi identik dengan kemampuan membaca informasi, memadukannya dengan tingkat kebutuhan, hingga pada kemampuan menyampaikannya ${ }^{4}$.

Model ini hampir memiliki kesamaan dengan model sistem komputer konvensional yang mempunyai pengolah (processor), memori, dan interaksi diantara keduanya melalui bus.

Urutan dari penerimaan informasi dalam diri manusia dijelaskan sebagai berikut: pengolahan perseptual dimana manusia menangkap informasi dari lingkungan melalui organ-organ sensorisnya yaitu: mata, telinga, hidung, lidah, dan kulit. Beberapa informasi disaring pada tingkat sensoris, kemudian sisanya dimasukkan dalam ingatan jangka pendek. Bila diproses lebih lanjut, informasi dari ingatan jangka pendek dapat ditransfer dalam ingatan jangka panjang. Ingatan jangka panjang merupakan tempat penyimpanan informasi yang faktual dan informasi bagaimana cara mengerjakan sesuatu.

Orang yang menguasai informasi memiliki kesempatan yang lebih besar untuk sukses, baik secara pribadi maupun konteks professional, sebab, di era sekarang, menguasai informasi berarti menguasai sumber daya.

${ }^{4}$ Richard J. Murnane and Frank Levy, Teaching the New Basic Skills. Principles for Educating Children To Thrive in a Changing Economy. (ERIC, 1996), 250, http://eric.ed.gov/?id=ED404456. 
Memahami perintah, memahami pesan, memahami kebutuhan orang lain, menggali lebih banyak informasi dibutuhkan sebagai modal agar dapat berkomunikasi serta menjadi kemampuan utama untuk dapat berhasil dalam setiap pekerjaan.

\section{Menjaga hubungan baik dengan masyarakat}

Secara fitrah manusia yang tercipta sebagai makhluk sosial memberikan kemungkinan bahwa manusia satu akan membutuhkan manusia yang lain untuk memenuhi kebutuhannya, baik kebutuhan individu maupun kebutuhan kolektif. Dalam konteks dunia kerja, membangun relasi dengan pihak lain menjadi penting, dan modalnya adalah kemampuan berkomunikasi yang baik yang dilandasi dengan pengetahuan dan pengalaman yang dimiliki setiap individu.

Jika melihat ke ranah yang lebih sempit di dunia kepustakawanan, maka sebagai pustakawan yang sudah masuk dalam katagori professional, maka menjalin hubungan dengan orang lain, baik dengan sesama pustakawan, dengan pemustaka, dengan organisasi profesi maupun dengan masyarakat, menjadi kewajiban yang harus dilakukan sebagaimana tercantum pada kode etiknya ${ }^{5}$.

Di perpustakaan sangat memungkinkan hubungan dengan orang lain ini terjadi. Misalnya dengan pemustaka, atau dengan pustakawan di lain instansi. Apalagi trend sekarang perpustakaan dalam rangka meningkatkan kebermanfaatan koleksi, perlu adanya kerjasama dengan perpustakaan lain. Disamping itu, akan menjembatani para pemustaka yang membutuhkan beragam koleksi.

\section{Kemampuan berjejaring sosial}

Suatu kegiatan yang menghubungkan kepentingan antarindividu, individu dengan kelompok atau antar kelompok yang secara langsung ataupun tidak langsung. Melvin L. DeFleur, menjelaskan bahwa hubungan sosial secara informal berperan penting dalam merubah perilaku seseorang ketika diterpa pesan komunikasi massa.

\footnotetext{
${ }^{5}$ Wiji Suwarno, Ilmu perpustakaan \& kode etik pustakawan (Yogyakarta: Arruz Media, 2010).
} 
Hubungan sosial merupakan hubungan antara dua atau lebih individu yang dapat saaling memengaruhi, mengubah dan memperbaiki tingkah laku karena dalam hubungan sosial terdapat emosi atau perasaan yang muncul saat berkomunikasi yang berupa kasih sayang, tolong menolong, perhatian hingga pemahaman terhadap perasaan orang lain (simpati dan empati).

Ada beberapa hal yang bisa dilakukan oleh individu dalam rangka membangun relasi dengan pihak lain, diantaranya:

a. Niat baik dan percaya diri dalam menghadapi orang lain, serta memulai dengan santun pembicaraan.

b. Berfikir secara cermat sebelum menyampaikan ide atau gagasan, atau berbicara dengan orang lain. Perlu dihindari perkataan yang membuat orang lain tersinggung, kecewa, depresi dan stress. Maka materi yang akan disampaikan perlu disusun dengan baik, sehingga pada saat bicara tidak melenceng dari apa yang sudah dipersiapkan.

c. Mempelajari latar belakang budaya atau kultur orang yang diajak bicara. Hal ini terkait dengan membangun relasi dengan orang yang berbeda pada setiap kesempatan ditempat kerja. Contoh: suatu ketika bisa saja individu bertemu dengan orang asing, kebetulan orang ini akan menjalin hubungan kerjasama antar instansi. Tentu strategi membangun relasi dengan orang asing ini akan berbeda dengan ketika membangun relasi dengan rekan sejawat.

d. Saat terjadi komunikasi, maka jurus menjadi pendengar yang baik perlu dikeluarkan. Karena orang akan merasa tertarik jika apa yang disampaikannya diperhatikan dan diapresiasi. ${ }^{6}$

Seorang professional perlu memiliki jiwa besar dalam memahami orang lain agar orang lain itu tidak berpandangan negatif. Boleh berdebat hebat, tetapi tidak melibatkan perasaan. Hal ini dikatakannya tidak mudah, tetapi sebagai seorang professional, tetap perlu mengupayakannya. ${ }^{7}$

\footnotetext{
${ }^{6}$ Sutatno, Soft Skill Sukses Di Dunia Kerja, 125-29.

${ }^{7}$ Febe Victoria Chen, Menciptakan keharmonisan di dunia kerja, Soft Skill For Success (Jakarta: Gramedia., 2012), 61.
} 
Hal yang menjadi rawan konflik biasanya ada satu pihak yang mematikan pendapat lawan dengan maksud agar lawan mengamini apa yang dipikirkannya. Sebenarnya bisa dihindari asalkan fokus pada pencapaian solusi dan bukan menunjukkan kehebatan. Menghargai sikap dan pendapat orang lain, bertutur kata dengan bahasa yang baik, mengendalikan diri, fokus pada problem solving, sedikit banyak akan mengurangi konflik karena perbedaan pendapat tadi.

\section{Kemampuan mengatur waktu}

Kemampuan mengelola waktu sendiri sehingga setiap tugas dapat terselesaikan sesuai jadwal yang telah direncanakan. Time Management skill ini diarahkan pada keterampilan seseorang dalam menetapkan, mengatur, memilih, memutuskan antara kualitas/tenaga untuk efektivitas dan produktivitas waktu. Implementasi time management biasanya berkutat pada kegiatan sebagai berikut:

- Menetapkan sebagai langkah pertama sebuah perencanaan.

- Mengatur untuk menjadikan dirinya dan schedule kerjanya rapi dan teratur.

- Memilih untuk menentukan hal yang paling relevan.

- Memutuskan merupakan satu keberanian untuk melakukan sesuatu yang telah dipikirkan, tentu dengan mempertimbangkan keberanian pula menghadapi resiko yang akan ditimbulkan.

- Kualitas merupakan seberapa baik sebuah produk yang dihasilkan apakah sesuai atau tidak dengan kebutuhan.

- Efektivitas merupakan tingkat dimana kinerja sesungguhnya sebanding dengan kinerja yang ditargetkan/pencapaian yang ditetapkan.

- Produktivitas waktu merupakan sejauh mana/seberapa lama tingkat sumber daya baik manusia/barang mampu menghasilkan suatu pekerjaan/berproduksi.

Untuk memaksimalkan implementasi Time management ini, perlu dibuat suatu pembiasaan dengan latihan atau kegiatan lain yang merangsang 
orang untuk melakukan time management. Mengapa pustakawan perlu diarahkan untuk hal demikian, tidak lain agar:

- Setiap pustakawan mampu menyeimbangkan dan memaksimalkan waktu dengan menggunakan perbandingan antara energi dan kualitas.

- Pustakawan dapat memahami dalam menetapkan, mengatur, memilih dan memutuskan antara kualitas/tenaga untuk efektivitas dan produktivitas waktu.

- Pustakawan dapat menghindari kepayahan waktu dimana energi meningkat namun kualitas yang dihasilkan rendah.

\section{Kemampuan interpersonal}

Interpersonal Skills adalah kemampuan dalam berhubungan baik kepada lawan bicara atau orang lain. Posisi individu (baca: pustakawan) dalam konteks ini adalah sebagai pendengar yang baik, dan tidak mudah menghakimi orang lain, suka berbagi ide dan masukan (Chen, 2012). Sebagai seorang yang mempunyai interpersonal skills pustakawan akan menjadi partner yang selalu sedia manakala rekan kerja membutuhkannya. Pakar lain mengatakan bahwa interpersonal skill adalah kecakapan atau keterampilan yang dimiliki oleh seseorang dalam hubungannya dengan orang lain, kecakapan atau keterampilan untuk berkomunikasi baik verbal maupun non verbal.

Ahli lainnya mengatakan bahwa interpersonal skill (keterampilan interpersonal) adalah suatu keterampilan untuk mengenali dan merespon secara layak perasaan, sikap dan perilaku, motivasi serta keinginan orang lain. Bagimana seseorang mampu membangun hubungan yang harmonis dengan memahami dan merespon manusia atau orang lain.

\section{Kemampuan berkomunikasi}

Komunikasi adalah terjadinya interaksi antara satu pihak dengan pihak lainnya dengan proses pengiriman pesan dari pengirim kepada penerima. Seperti halnya orang berbincang-bincang, diantara keduanya disyaratkan adanya kepercayaan, hubungan batin yang memberi hak untuk 
saling berbagi informasi ${ }^{8}$.

Dalam penyampaiannya, informasi bisa disampaikan dengan bahasa verbal (lisan) maupun non-verbal (bahasa tulis, bahasa tubuh, isyarat). Dalam komunikasi verbal ada dua komponen pokok yang perlu dimiliki oleh seseorang, yaitu komponen kecerdasan bahasa dan komponen kecerdasan berkomunikasi.

Bagi pustakawan, dengan kemampuan berkomunikasi, maka ide-ide brilian akan mudah disampaikan dan dipahamai pihak pimpinan dan pihak terkait lainnya, sehingga memudahkan dalam merealisasikan programprogramnya.

\section{Kesimpulan}

Sebagai penutup dapat disimpulkan bahwa sedikitinya uuntuk menjadikan pustakawan ini eksis, harus memiliki keterampilan mendengarkan, kemampuan menerima informasi dengan baik, menjaga hubungan masyaakat, kemampuan menjaga hubungan sosial, menjaga hubungan interpersonal, menjaga hubungan kemampuan mengatur waktu dengan baik, dan membangun komunikasi dengan siapa pun, maka eksistensi diri sebagai pustakawan dan juga nama pustakawan itu sendiri akan menjadi dihargai, dipandang baik, dan lebih dapat menjadi mata rantai berharga bagi perkembangan ilmu pengetahuan.

\section{Daftar Pustaka}

Chen, Febe Victoria. Menciptakan keharmonisan di dunia kerja. Soft Skill For Success. Jakarta: Gramedia., 2012.

MacKellar, Pamela H. The Accidental Librarian. Medford, N.J: Information Today, Inc, 2008.

Mulyono, Iyo. Dari Karya Tulis Ilmiah Sampai Dengan Soft Skills. Yogyakarta: Yrama Widya, 2011.

${ }^{8}$ Iyo Mulyono, Dari Karya Tulis Ilmiah Sampai Dengan Soft Skills (Yogyakarta: Yrama Widya, 2011), 11. 
Murnane, Richard J., and Frank Levy. Teaching the New Basic Skills. Principles for Educating Children To Thrive in a Changing Economy. ERIC, 1996. http://eric.ed.gov/?id=ED404456.

Robles, Marcel M. "Executive Perceptions of the Top 10 Soft Skills Needed in Today's Workplace." Business Communication Quarterly 75, no. 4 (2012): 453-465.

Sutatno, Teguh. Soft Skill Sukses Di Dunia Kerja. Yogyakarta: Buku Pintar, 2012.

Suwarno, Wiji. Ilmu perpustakaan \& kode etik pustakawan. Yogyakarta: Arruz Media, 2010. 